Studia Anglica Posnaniensia 57 (2022): 5-32

doi: 10.2478/stap-2022-0001

\title{
URBAN IMAGERY IN THE OLD ENGLISH EXODUS AND ITS HERMENEUTICS
}

\author{
JACEK OLESIEJKO*
}

\begin{abstract}
The present article offers a critical reading of the Old English Exodus, a poem that is an Old English versified adaptation of an episode from the biblical story of Exodus that narrates Israelites' passage across the Red Sea and the destruction of Pharaoh's army. The aim of this article is to analyse the poem's urban and exilic imagery that strongly relies on the metaphorical representation of the Israelites as a city, as they are actually in exile and on the way to Canaan, and of the metaphorical representation of the walls of the Red Sea as the walls of a hall that is destroyed along with the Egyptian army. The argument of the present article is that in Exodus the poet uses the imagery of a hall and exile, derived from heroic and secular verse, as a hermeneutic key to read the biblical exodus typologically, tropologically, and anagogically. The metaphor of the key that opens the Scripture, which the poet uses in Exodus, encourages the reader to unveil the hidden meaning of the narrative. The poet inverts the conventional imagery of the hall and exile in the poem to emphasise narrative moments that require the reader to explore the letter of the poem for additional layers or signification.
\end{abstract}

Keywords: Old English Exodus; Old English poetry; Old English literature; Old English biblical verse; early medieval England.

\section{Introduction}

The biblical Old English poem Exodus, preserved in one copy in MS. Junius 11 , dated to the half-century ending around the year 1000 A.D, ${ }^{1}$ is a retelling of

* Assistant Professor, Faculty of English, Adam Mickiewicz University, ul. Grunwaldzka 6, 60-780 Poznań, Poland, e-mail: olesiejk@ amu.edu.pl.

1 The manuscript, which has suffered some loss of verse, contains other Old Testament poems in Old English, namely, Genesis A, Genesis B as well as Daniel. Another poem, alluding more strongly to the New Testament, Christ and Satan, ends the manuscript. Exodus had been composed much earlier than the time of the compilation of the manuscript. Peter J. Lucas in his edition of the poem argues for 700 as terminus a quo and for 800 as terminus ad quem (Lucas 2020: 71). The later date makes Bede's influence suggested in the present article plausible. 
the passage of the Red Sea that is strongly pervaded by the traditions of Old English heroic verse. Striking for its subject of a maritime adventure, the poem's natural landscape, the desert which the Israelites must negotiate to escape from Egypt and the Red Sea itself as its waters part, is recurrently described in terms of an opposition between the cities of the Egyptians and a metaphorical city which the peregrinating Israelites comprise. The poet introduces into his biblical source an imaginative distinction between literal and metaphorical cities; while presenting God's destruction of the Egyptian firstborn sons as an assault on a hall, he describes the travelling Israelites to form a metaphorical city on the move, "mægburh" [lit. family-enclosure, family-city, translation mine $]^{2}$ (Exodus, 1. 55b) ${ }^{3}$, on the march towards the Red Sea and, ultimately, to the promised land. The urban imagery that pervades their passage across the desert and the sea clearly implies, as Denis Ferhatović recently observed, "that they remain in a type of a city after leaving behind the civilisation of the Egyptians" (Ferhatović 2019: 71).

In addition to the poem's representation of the Israelites' travelling city, the poem also depicts their wanderings across the desert as sea travel. The text presents the literal seas along with metaphorical ones, as the Israelites are described as "sæ-men" [sailors] (Exodus, 1. 105b) while travelling on land towards the Red Sea, protected by a pillar of cloud described by the poet as a sail. The conflation of the urban imagery and maritime motifs in the poem comes to its climax when the Red Sea, as it parts miraculously, becomes another city, whose walls of water act as protective ramparts sheltering the Israelites from their enemies, and which fall on the Egyptians who drown in the depths of the sea. The aim of the present article is to explore the conflation and inversion of urban and maritime spaces that informs the narrative of Exodus and to elucidate their artistic consistency. It is argued here that the poem is structured by a reversal of symbols that are associated with life in a protective enclosure and exile, symbols that derive from the secular Germanic, originally pagan, poetic imagery that relies on the representation of the hall and human architecture as a symbol of society and social order. In Exodus, symbols of protection, enclosure, exile, and danger are confused and inverted, as cities signify spiritual exile leading to death, while literal exile anchors the Israelites in their hope of the Promised Land, which for the poem's Christian audience mystically and allegorically represents eternal life. The argument advanced in the study is that

2 In her Inhabited spaces, Discenza discusses the use of moegburh in the Old English Genesis A, which precedes Exodus in the Junius Manuscript. However, her discussion does not include the appearance of moegburh in Exodus.

3 All quotations from the Old English Exodus come from the most recent edition of the poem by Peter J. Lucas (2020). Translations into Modern English come from Daniel Anlezark's (2011) edition and his translation of Junius' poems. His translation of Exodus has been chosen for its literary quality. 
the poem's urban and exilic imagery serves as a hermeneutic tool, a key that opens the poem's hidden, allegorical meaning.

There is general consensus that the poem may accommodate an allegorical interpretation insofar as the poet uses the metaphor of the key that opens the book of Scripture. The text's hidden meaning (or, perhaps, the meaning of the exodus generally) will be unveiled, "gif onlucan wile lifes wealhstod, beorht in breostum, banhuses weard, ginfæsten god Gastes cægon" [if life's interpreter, the body's guardian, wishes to unlock the abundant good, bright in the breast, with the keys of the spirit] (Exodus, 11. 523a-525b). In early medieval England, Bede followed a fourfold scheme of exegesis that discussed the typological, tropological, and anagogical levels of biblical texts in addition to their historical and literal meaning. As Peter J. Lucas observes, citing Erich Auerbach, in his recent edition of the poem, "the basis of typology is that a connection is established between two events fixed in historical time, 'the first of which signifies not only itself but also the second [which it foreshadows], while the second encompasses or fulfils the first"' (Lucas 2020: 55). As he observes, the exodus in the poem might be read typologically as a prefiguration of salvation since "the New Testament provides a typological reading of the event as a prefiguration of the Redemption, fulfilled by Christ under the new covenant ['I called my son out of Egypt': Matt 2.15]" (Lucas 2020: 55). Stephen E. C. Hopkins suggests that the cry of wolves prior to the description of the Israelites crossing the Red Sea is tropological as it is related to the Israelites not losing their spirit and faith when they face their fear of Pharaoh and the sea (Hopkins 2018: 10). Tropologically, or in the moral sense, the image of undaunted Israelites is therefore an example of faith and obedience, an example worthy of emulation. The last mystical level is the anagogical one, and teaches about the eschaton and afterlife. This sense is present in the description of the death of the Egyptian first-born and Pharaoh's army. The anagogical level of the poem has recently been discussed by Hopkins who claims that the destruction of Pharaoh's army as well as the wolves in the Beasts of Battle device represent the "enemies of the church paving the way to the eschaton with violence and treachery" (Hopkins 2018: 10).

Many critics have thus interpreted Israel's exodus from Egypt in the poem, the journey across the desert and the crossing of the Red Sea, as an allegory, usually by trying to prove that the poem's phrasing reveals the poet's knowledge of biblical commentaries written by the Doctors of the Church or some of the numerous New Testament passages that provide an allegorical exposition of the story. James Earl adduces citations from the commentaries by Zeno and Cassiodorus to illustrate the widely disseminated Christian tradition that the passage of the Red Sea "represents the journey of the Christian soul as it moves toward salvation by means of Christ and the Church" (Earl 1970: 545). He also 
claims that the word "bealusið" [a difficult journey] (Exodus, 1. 5) "summarises a long exegetical tradition that interprets the wanderings in the wilderness which precede the entrance into the Promised Land (or the life of bondage in Egypt which precedes the salvation of the Red Sea) as a period of temptation and $\sin$ in this life" (Earl 1970: 546). John Vickrey argued that the passage of the Red Sea signifies the Christian perception of baptism as a spiritual battle with seven deadly sins (Vickrey 1972: 121). Vickrey drew on Paul's discussion of baptism in Romans 6.6 as well as Augustine's exposition of Psalm 72 in Enarrationes in Psalmos (Vickrey 1972: 122). Maxwell Luria suggested that both Moses and Noah in Exodus are types of Christ, while Noah's ark mentioned in the poem is a type of the church (Luria 1981: 604). Miranda Wilcox finds it plausible that the Exodus poet was exposed not only to the practice of biblical exegesis, but also to an allegorical biblical poem authored by Arator, Historia Apostolica, and Bede's Expositio Actuum Apostolarum (Wilcox 2011: 129). ${ }^{4}$

There have also been more recent interpretations of the poem's allegorical meanings, which differ from earlier patristic readings of Exodus insofar as they discuss the poet's investment in the role of the reader rather than the direct or indirect influence of patristic sources on the text. Audrey Walton argues that the opening lines of the poem and the metaphor of the key "place the reader in the position of an interpreter, requiring him or her to read for manifold senses of the text rather relying passively on the poem to supply the allegorical meaning of the narrative" (Walton 2013: 1). ${ }^{5}$ Stephen C. E. Hopkins also discusses the poem as containing multiple levels of allegorical meaning and elucidates the way the trope of Beasts of Battle functions within the fourfold exegetical paradigm in Exodus. He claims that the wolves influence each level, by charging it with the emotion of fear (Hopkins 2018: 9). Discussing the Exodus poet's reliance on formulaic tropes of pagan Germanic poetry, Stephen C. E. Hopkins convincingly argues that the poet uses the Beasts of Battle trope to heighten the allegorical interpretation encouraged by the poem's opening lines. ${ }^{6}$ He concludes that the

4 She argues that "Arator's figural interpretation of the two apostles Peter and Paul may have inspired the Exodus poet's conceit of the pillar of cloud as simultaneously a tent and a ship" (Wilcox 2011: 109).

5 She also argues that "the fourfold senses of Exodus are copresent in the text" and that the description of the spoils at the end of the poem "offers a metaphor for the practice of interpretation" (Walton 2013: 2). In addition, she claims that the ending of the poem is informed by the "gold out of Egypt" trope, which was developed by Augustine in De Doctrina Christiana (Walton 2013: 2-3)

6 He argues, for example, that the wolf that forms part of the triad of the wolf, the eagle, and the raven in the Old English Beast of Battle topos, a narrative device that introduces descriptions of battles, can be read allegorically as the devil defeated in the sacrament of baptism and anagogically as the enemy of the Church in the times prior to the Judgement Day (Hopkins 2018: 10). 
poem requires the audience to be familiar with exegesis as well as secular poetic conventions (Hopkins 2018: 19).

Building on Hopkins's idea that the Old English biblical poetry uses familiar heroic tropes to encourage an allegorical interpretation of a vernacular poem, I would like to argue that a polyvalent reading of the Old English Exodus is facilitated by the poem's reliance on the Germanic heroic concepts of hall and exile. As will be shown in the following pages, the poet describes the Egyptian cities by means of formulaic expressions derived from secular poetic representations of halls and exile that characterise such Old English poems as Beowulf. While the Egyptians are depicted as bound and captive in cities, suffering loss and bereavement that in Old English poetry are the experiences of exiles, the Israelites are presented as liberated in their journey. The Egyptian cities represent an Augustinian city of men and form a backdrop for a typological reading of the Israelites' moegburh as a prefiguration of the Church. ${ }^{7}$ Anagogically, the destruction of Pharaoh's army is a type of the Judgement Day and the urban imagery informing the fragment further juxtaposes their existence in earthly cities against Israel's liberating travel. Tropologically, cities represent transient values that disrupt the pilgrims' attention on their heavenly home. The following reading of the poem will thus acknowledge the significant role that the Germanic secular poetics plays in the poem.

The historical and heroic level of the narrative provides an additional figural dimension of the exodus; the exodus of Israel is a historical precedent for Germanic migration and conversion. Another wave of critics historicise the Old English adaptation, while not objecting to the exegetical method as such. Since the publication of Nicholas Howe's Myth and Mythmaking in Anglo-Saxon England in 1989, Israel's exodus from Egypt present in the poem has been figurally applied to the political history of Gens Anglorum. Nicholas Howe was the first to claim that the Exodus poet forges a correspondence between the exodus of the Hebrews from Egypt and the ancestors of Germanic tribes who travelled from the continent to Britain; the poet, he argues, incorporates "Anglo-Saxon migration into biblical history" (Howe 1989: 98). Like Howe, Fabienne L. Michelet discusses the Old English Exodus in the context of the Germanic myth of migration as the founding myth of the origin of the early medieval English cultural identity (Michelet 2011: 59-60). Placing the poem in the cultural context of other works reproducing the myth of migration as the founding event for early medieval England, Bede's Historia Ecclesiastica Gentis Anglorum and the Anglo-Saxon Chronicle, she postulates that the memory of migration reminded early medieval English people of the conquest of the land that had earlier been settled and inhabited, as well as of

7 The depiction of the Church as a ship travelling on the sea of life, navis ecclesiae, was also commonplace by the time the poem had been composed. 
their status as pagan settlers displacing the Christian Britons (Michelet 2011: 61). Michelet also argues that the memory of adventus Saxonum, the migration of Germanic tribes from the mainland continent to Britain in the fifth century, pervades the Old English Exodus (Michelet 2011: 71).

Although the poem centres on the crossing and its allegorical meaning, it ends with the promise of conquest and settlement that Howe and Michelet find to be an important ideological aspect of the poem. In addition, despite the fact that the poet requires the audience to read the journey that the Israelites make allegorically, he also puts into Moses's mouth the promise of the covenant that will confer on the Israelites' land and "beorselas" [beer-halls] (Exodus, 1. 564a) once they reach their destination. The second purpose of the article is to elucidate the relationship between the allegorical matter of the poem and the promise of the conquest of a permanent land. There is a manifest tension in the poem between the promise of land articulated at the end of the poem and the sustained criticism of urban space in the episodes that narrate Israel's escape from Egypt and the crossing:

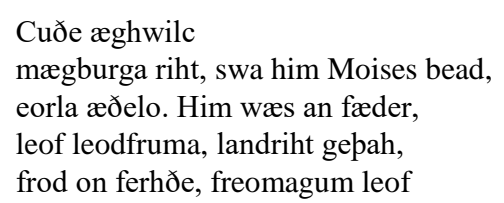

Each one [of the Israelites crossing the sea, JO] knew his tribal right, as Moses had instructed them, the lineage of noblemen. For them there was one father, beloved origin of the people, and he received the land-right, wise in spirit, dear to noblemen.

(Exodus, 11. 351b-355b)

While the Israelites' flight in the Old English Exodus might be interpreted as an archetype of the pilgrim to the other world turning away from transient values, the poem also asserts Israel's dependence on land and longing for a temporal homeland. Not only are the Israelites called "eorðbuende" [earth-dwelling] (Exodus, 1. 84a), but also the narrator strongly asserts that their land-right traced to Abraham's covenant with God validates the Israelites' claim for the land of Canaan. The following pages will thus relate the poem's explicitly articulated idea of land-right and covenant that promise an establishment of permanent home to the Christian concept of life as exile as well as the Augustinian contrast between the city of men and the City of God that may have influenced Exodus. Since the subject of the poem is the relationship between the conception of life as an exile that derives from patristic interpretation of the Old Testament Exodus and the hall imagery originating in secular heroic poetry, the next section will present the use of urban imagery in both, the patristic and Germanic, traditions. 


\section{Cities in patristic literature and halls in Old English poetry}

Formulations of the life of Christians as exiles from their extraterrestrial homeland had been a commonplace by the time of the poem's composition. The formulation was widely disseminated in Augustine's writings and recurrent in his discussions of the contrast between the city of men and the City of God. ${ }^{8}$ In Exodus, the contrast between the Israelites as sea-travellers in exile and the Egyptians as city-dwellers might be strongly evocative of the Augustinian distinction between the citizens of civitas terrena, the earthly city, with Babylon as its archetype, and the celestial city of God, with Jerusalem as its archetype. Both groups of citizen inhabit the Earth temporarily and live in a mixed society: "God's City lives in this world's city, as far as its human element is concerned; but it lives there as an alien sojourner" (De Ciuitate Dei 18.1). ${ }^{9}$ The assumption that the true location of the City of God is extraterrestrial implies a perception that Christians must conceive of their lives in terms of displacement. It is such a sense of displacement that, Augustine argues, defines the elect.

In addition, in De Doctrina Christiana, Augustine claims that those who are elect to become citizens of the City of God are exiles who are on a pilgrimage to another home and must not take pleasure in transient material goods. Still, these goods are necessary for the duration of the pilgrimage; they must be used, but not enjoyed.

Suppose we were travellers who could live happily only in our homeland, and because our absence made us unhappy we wished to put an end to our misery and return there: we would need transport by land or sea which we could use to travel to our homeland, the object of our enjoyment. But if we were fascinated by the delights of the journey and the actual travelling, we would be perversely enjoying things that we should be using; and we would be reluctant to finish our journey quickly, being ensnared in the wrong kind of pleasure and estranged from the homeland whose pleasures could make us happy. So in this mortal life we are like travellers away from our Lord: if we wish to return to the homeland where we can be happy, we must use this world, not enjoy it.

(De Doctrina Christiana, 9-10) $)^{10}$

8 The texts of Augustine's De Ciuitate Dei and De Doctrina Christiana were accessible in some Anglo-Saxon libraries. As demonstrated by Michael Lapidge in The Anglo-Saxon Library, Bede quoted from both De Ciuitate Dei (Lapidge 2006: 197) and De Doctrina Christiana (2006: 199). All quotations from Augustine's De Ciuitate Dei come from Augustine (2003).

10 All quotations from Augustine's De Doctrina Christiana come from Augustine (1997). A corresponding distinction between the permissible use of earthly goods and prohibited enjoyment of them is expressly articulated in Augustine's De Ciuitate Dei: "The whole family of the servants of the supreme and true God has its consolation, which never disappoints, which does not depend on hope in shifting and transitory things... They enjoy their earthly blessings in the manner of pilgrims and they are not attached to them, while these earthly misfortunes serve for testing and correction" (De Ciuitate Dei, 41). 
As regards the commonplace of describing Christians as pilgrims, Martin A. Claussen, in his study of the concept of pilgrimage in Augustine's works, argues that the early Christian characterisation of members of the Church as travellers (peregrini) was not only a metaphor but also a description of the Christian actual legal status (Claussen 1991: 47). While they do inhabit this world, they are peregrini, a word whose meaning in Augustine's usage ranges from pilgrims to exiles, alienated from this world, both metaphorically and literally, being not entitled to the enjoyment of this world's values. Claussen argues that the legal basis for Augustine's perception of the relationship between peregrini and the city of men was pivoted on the distinction between the use and enjoyment of earthly values (Claussen 1991: 49). Christians are peregrini not metaphorically, but in reality, as, in contrast to the citizens of the Earth, they do not lay claim to exercising dominion over worldly possessions. While the citizens of the earthly city lay a claim to the full enjoyment of possessions, peregrini are only entitled to the use of terrestrial goods without the right to ownership (Claussen 1991: 51).

Bede and his biblical commentaries are another source from which the poet may have derived the urban imagery that he uses to sustain the poem's polyvalent structure. Exodus was composed early in the Old English period; Peter J. Lucas in his edition of the poem argues for the year 700 A.D. as terminus a quo and for the year 800 A.D. as terminus ad quem (Lucas 2020: 71), although the influence of Bede might point to a date in the latter two-thirds of that century. In Bede's Commentary on Genesis, dated from 709/711 to 720 A.D., the origin of evil with the event of Cain killing his brother Abel is the origin of two societies, one that descended from Cain, the other from Seth, who was born to Adam and Eve after Abel's death. Bede associates the former with the life in cities, while the latter with the life in tents. For Bede, it is the fact that the descendants of Seth do not live in cities that qualifies them as the elect. Their life in tents indicates that they "are found to have led a simple life as strangers on Earth" (In Genesim, 156). Like Augustine, Bede distinguishes between the citizens of the Earth who preoccupy themselves with "the refinement and the embellishment and the charms of this life", which he associates with life in cities, and the elect who "either renounce these things entirely, or use them in passing for the sake of some proper purpose of this life until they reach eternity, just as a traveller uses a stable or travelling money" (In Genesim, 156-157).

Bede also establishes a strong typological link between the nomadic Israelites and the English, a link that may precede a similar typology explored in Exodus. Bede represents the nomadic existence and life in tents as a symbol of a spiritual struggle with the devil as well as a more general symbol of the life of a Christian. Significantly, the commentary on Genesis links the concept of life as pilgrimage with the concept of life as a spiritual warfare. 


\begin{abstract}
May God enlarge Japheth, and may he dwell in the tents of Shem. Japheth, of course, may dwell in the tents of Shem, because the Church wanders on Earth in the faith of the patriarchs and prophets - in the prophetic Scriptures, and in the sacraments of the Law, spiritually understood. For indeed we are accustomed to use tents in war or on a journey, and we, who come from the Gentiles to Christ, dwell in the tents of the Israelite people, because truly as long as we, who are placed on the road of this life, sigh for our heavenly fatherland, as long as we struggle, under the leadership and guidance of Christ, against the snares of the old enemy, we must always keep firmly in mind at once the words and the deeds and the works of the ancient fathers as an example of life and faith.
\end{abstract}

$(\text { In Genesim, 212) })^{11}$

Bede's use of the pronoun "we" includes his English Northumbrian readers who are thereby invited to draw parallels between the Israelites' nomadic way of life and the Christian perception of life as a pilgrimage. Bede juxtaposes the historical journey of the Israelites with the concept of the life of Christians as a pilgrimage that he sets as a model for his English readers. In addition, he presupposes that his audience will find the image of tents used in warfare and in travelling familiar and evocative of their ancestors' migration from the continental Germania to Britain. Bede's general association of tents with travel that he makes in the context of his figural interpretation of the Old Testament Tabernacle in his Commentarius in Ezram et Neemiam, dated to 711/715 A.D., might also be understood as an allusion to Germanic migration, an allusion that presents ancestral history in the context of biblical typology. ${ }^{12}$

The Exodus poet draws inspiration from yet other sources, namely, the Germanic poetic tradition, the hall imagery that is recurrent in the Old English heroic poetry as well as Germanic kinship values. The symbolism of the hall is described by Katherine Hume in her 1974 seminal article "The concept of the hall in Old English poetry", where she demonstrates that what Old English poems "celebrate is, of course, not simply the hall as a building but the social system associated with it" (Hume 1974: 64). She claims that "the hall was pictured, for poetic purposes, as a circle of light and peace enclosed by darkness, discomfort and danger" (Hume 1974: 64). As she observes, urban space is also a refuge as

11 All translations from Commentarius in genesim come from Bede's On Genesis (2008).

12 In Commentarius in Ezram et Neemiam, Bede claims that "our fathers too, therefore, were set free from slavery in Egypt through the blood of the lamb and were led through the desert for forty years that they might come to the Promised Land when through the Lord's passion the world was set free from slavery to the devil and through the apostles the primitive Church was gathered and was led as it were through the desert for forty years until it came to the homeland promised in heaven ... In remembrance of this time, we too ought to dwell in tabernacles, leaving our homes - that is, having forsaken the cares and pleasures of the world, we ought to confess that we are pilgrims in this life and homeland in heaven, and desire that we may arrive there all the more quickly" (Commentarius in Ezram et Neemiam, 196-197). All quotations from Commentarius in Ezram et Neemiam come from Bede's On Ezra and Nehemiah (2006) 
"the forces of opposition that ranged against the burh and the hall as its principal building were - as one might expect from the etymology of burh (beorgan, 'to protect, shelter') - of great importance to poetic usage" (Hume 1974: 66). As she observes, urban space is also a refuge, for "the forces of opposition that ranged against the burh and the hall as its principal building were - as one might expect from the etymology of burh (beorgan, 'to protect, shelter') - of great importance to poetic usage" (Hume 1974: 66). The existence of an ideal hall presupposes an opposite and, as she demonstrates, the dwellings of enemies are represented as anti-halls (Hume 1974: 68). In Beowulf, for example, Grendel and his Mother's dwelling has many features of a typical hall. "It is a hof, niðsele, hofsele, reced; it has a flet, treasure and walls hung with weapons. In harmony with this style of dwelling, Grendel's mother is an ides as well as an aglcecwif' (Hume 1974: 68). While Hume emphasises the polarity between human halls and monstrous anti-halls, however, it should be noted that Beowulf defies such a clearcut binary. As Nicole Guenther Discenza observes in her more recent discussion of space in Old English literature, Heorot is under three kinds of threats, "threats from outsiders, threats from within, and threats from time" (Discenza 2017: 184). Since Heorot in Beowulf is predicted to be consumed by fire as a result of a family feud, the apparent idealisation of the hall as a symbol of harmony is hence complicated, if not compromised (Discenza 2017: 187).

The Exodus poet's manipulation of the imagery associated with the hall, arguably, serves to adapt the patristic allegorical idea of exile and cities in a poem addressed to an audience that valued secular poetics in addition to biblical learning. He utilises both traditional symbolism of the hall that presents this type of building as sustaining the life of the community and family as well as its reversals and contradictions that can be identified in many Old English poems. However, the Egyptian cities are not anti-halls inhabited by enemies hostile to a poem's protagonists that Hume describes as negations and inversions of the hall. At the centre of the Egyptian social life, the hall is an image of corruption as such, not an image of transience that presupposes an existence of an alternative hall in which one can find refuge. Presenting exile as a desired alternative to an urban life is an unexpected feature in a text that relies on familiar tropes, an anomaly that disrupts a reception of a text for early medieval English recipients of the poem who must rely on stock formulaic phrases, themes, and tropes to appreciate a poem. It is exactly such a textual anomaly that warrants an allegorical reading according to Augustine in De Doctrina Christiana. ${ }^{13}$ In harmony with the expectations of exegetes, this anomaly emerges as a consistent, paradoxical and sustained reversal

13 In Book III of De Doctrina Christiana, Augustine says that persons and actions that have no congruity with Christian morals tend to be signs which represent a deeper sense that must be unveiled in the process of the interpretation (De Doctrina Christiana, 80). In Book IV he gives an example of Noah's drunkenness. Although drunkenness is not exemplary, Noah's drunkenness is a type of Christ's passion (De Doctrina Christiana, 132). 
of symbols associated with life in the hall and exile, a reversal that contrasts cities as evil and filled with death and exile as desired and leading to life. Since the use of pagan learning is permissible in De Doctrina Christiana, the Exodus poet's adaption of Germanic secular concepts for his exposition of a biblical narrative and its manifold senses using a familiar poetic concept is acceptable. ${ }^{14}$

In addition to patristic, and heroic, influences on the poem's urban imagery, the very fact that some of the poem's early medieval audiences lived in sophisticated urban settlements must also be taken into account. In early medieval England, burghal cities, as Richard North and Michael D.J. Bintley note in their recent edition of the Old English poem Andreas, were either based on earlier Roman cities or built in imitation of them (North \& Bintley 2016: 94). The Ruin, a poem from the Exeter Book, describes the remains of an ancient city that has often been identified as Bath, a city raised in the times when Britain was a Roman colony and subsequently fallen into ruin.

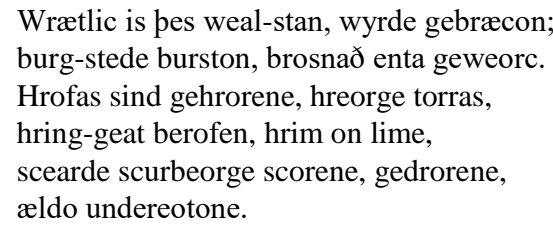

Wondrous is this wall stone; disastrous events have shattered it; the fortified cities have broken apart, the work of giants decays. Roofs have fallen, towers are ruinous, the ring gate is destroyed, frost is on the mortar, the gaping protectors against storms are rent, have collapsed, undermined by age.

(The Ruin, 11. 1-6a) $)^{15}$

According to Nicholas Howe, such Roman sites that remained in the early medieval English landscape constituted a postcolonial void created as a result of the Roman army leaving the British Province after 410 A.D., a post-colonial void that stimulated the incoming Germanic settlers' perception that they had a historical role to fulfil in recolonising and re-Christianising the English landscape (Howe 2008: 76). In addition, cities did not only function as symbols of a glorious past that was perceived as worthy of emulation. Early medieval English people had not only knowledge of distant cities and their importance; as some of them

14 The argument that the episode of the Israelites sharing Egyptian spoils presented at the end of the poem not only encourages allegorical interpretation but also evokes the metaphor of the adaptation of pagan culture as a textual spoilation used by Augustine in De Doctrina Christiana is developed by Audrey Walton in her article "The Old English Exodus and the reader as exegete" (Walton 2013: 2)

15 The quotation from the Old English Ruin, as well as the translation, come from Robert R. Bjork' edition (2014). 
travelled to Rome and Jerusalem, they returned with stories in which cities were vital symbols of learning and the civilised world. ${ }^{16}$

In addition, the idea of burh that recurs in the poem may have accumulated additional historical and political associations in different stages of the poem's reception in the tenth and early eleventh century that culminated in the transcription of Exodus in the Junius Manuscript around 1000 A.D. In their study of civil defence in early medieval England in the times of the Viking invasions, Baker and Brooks demonstrate that "the significance of Old English burh ... has attracted a wide range of meanings, covering both fortified sites (real, figurative, or spiritual), and towns" (Baker \& Brooks 2013: 95). It is plausible that the noun has its roots in the verb beorgan, 'protect', as Simon Draper suggests (Draper 2008: 240), and there seems to be an agreement that "enclosure" is not only an essential feature of any early medieval English burh but also its actual meaning (Draper 2008: 240) ${ }^{17}$ Fortifications built on the coast of the British Isles to defend England against Viking attackers were not only connected with the sea, as the poem's metaphorical moegburh is, but also accumulated a range of connotations that reverberate in the poem's description of Pharaoh's army approaching the Israelites on shore before they cross the sea. ${ }^{18}$ The defensive, protective function of the hall is an important idea that complements the association of the life in the hall with prosperity, on which the poet falls back upon when he describes the Israelites' moegburh protected physically and spiritually by the pillar of fire.

\section{The imagery of the hall and allegory}

The Exodus poet relies on the audience's knowledge of the trope of the hall as the symbol of social order. The reversal of symbols that he creates in the composition could only be appreciated by an audience familiar with Germanic heroic poetics. In the poet's manipulation of the heroic trope of the hall, the urban enclosure accumulates a range of negative connotations that are not only the opposite of the prosperity associated with a life in the proximity of the hall, but also connotations of exile. While the idea of the city as a protective and defensive

16 Burh was used to refer to Rome and Jerusalem; Rome was "a paradigmatic city"; the dating formula ab urbe condita was frequently used in the Anglo-Saxon Chronicle (Discenza 2017: 197). Early medieval English people used the word to refer to their own urban spaces. Discenza notes the aspirational usage of the concept of the city in early medieval English descriptions of their own habitations (2017: 199).

17 Baker \& Brooks (2013: 95) concur with Parsons and Styles's earlier suggestion that the most defining characteristic of burh is "the presence of an outer wall, rampart, or fence" (Parsons \& Styles 2000: 76-77).

18 The possibility that Viking invasions formed a backdrop for the poem's reception in the ninth and tenth century is discussed by Stephen C. E. Hopkins's article "Snared by the beasts of battle" (Hopkins 2018: 4). 
space is very common in Old English heroic verse, in Exodus the Egyptian cities are places of destruction and death. The poet's account of the tenth plague, visited on the Egyptians as punishment for their refusal to grant Israel freedom to leave Egypt, is pervaded by such reversed symbolism of cities and halls. It is made manifest by the poet that the confines of Egyptian cities fail in their protective capacity when the Passover Angel descends on Egypt.

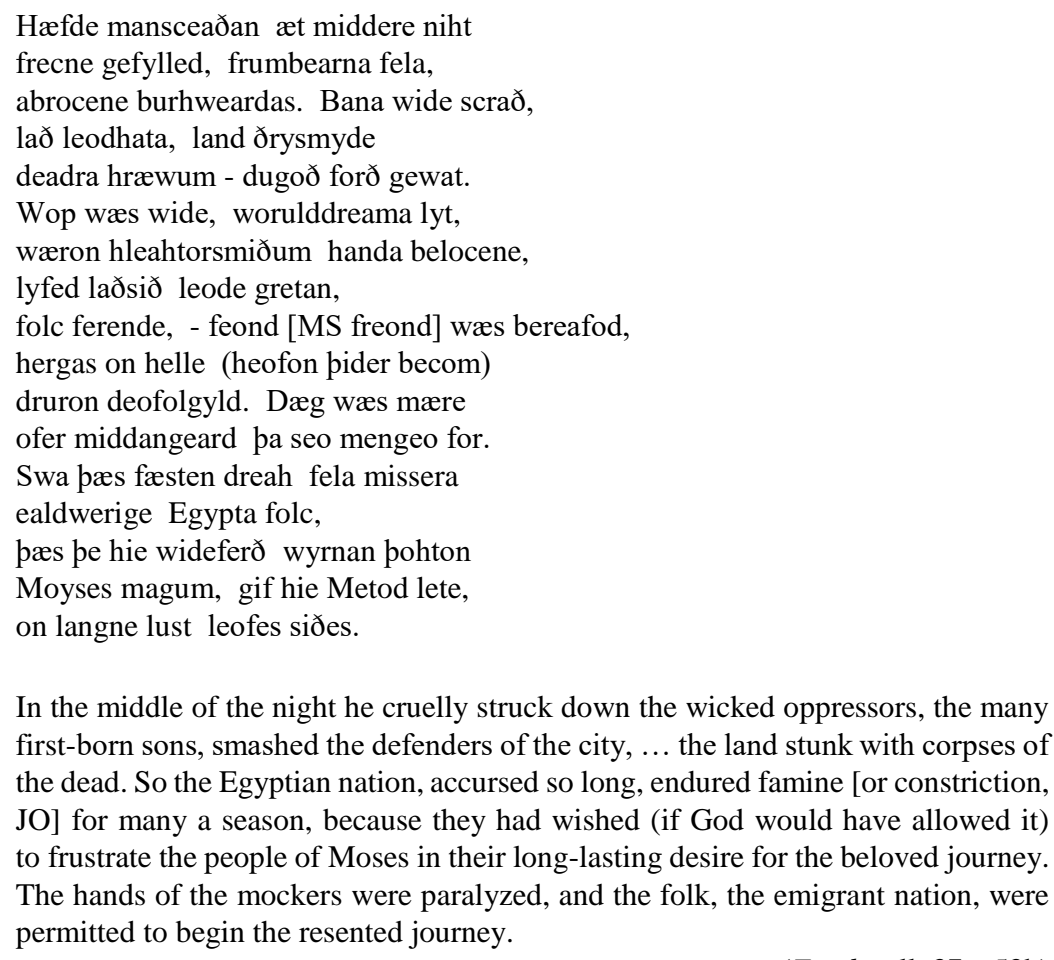

(Exodus, 11. 37a-53b)

The "burhweardas" [defenders of the city] (Exodus, 1. 39a) failed to protect their people from the attack. The passage also emphasises the constrictive confines of the city that is described as "fæsten" in line 49a. In his edition of the poem, Edward Irving suggests that the "fæsten" of line 49a is ambiguous and can be understood to mean either 'captivity' or 'famine'. He suggests the following translation of the passage: "So the people of Egypt endured captivity (?) for many years" (Irving 1953: 70). More recently, Daniel Anlezark (2011) translated "fæsten" as "famine" in his edition of Junius poems (his translation of Exodus into modern English follows the Old English text above). In Old English, feesten can generally mean "stronghold" or "fortification'. In the most recent edition of Exodus, Peter J. Lucas suggests 'confinement' (Lucas 2020: 82) as a more appropriate translation. He claims that "the Egyptians (seen allegorically as followers of the devil) endured 
confinement in Hell (a concept denoted by faesten in Whale 70)" (Lucas 2020: 82). If faesten is read as 'fortification' in line 49a, the word confers another negative connotation on the poem's representations of cities.

The atmosphere of confinement and constriction that prevails in Egypt creates a metaphorical link between the pagan urban space and Hell. The depiction of the space that the Egyptians inhabit as an oppressive enclosure is influenced by the poet's Christian perspective and has been found to be strongly evocative of descriptions of Hell found in the Old English poetic accounts of, and allusions to, Christ's Harrowing of Hell before the resurrection. In his edition of the poem, Lucas claims that "heofon probably denotes the divine power which descended into Egypt to free the Israelites, thus typifying Christ's descent to liberate the patriarchs from Hell" (2020: 82) ${ }^{19}$ The Egyptians are "hergas on helle" [hordes in Hell] (Exodus, 1. 46a); they signify the condemned. The loss of prosperity on the part of the Egyptian is conceptualised as a journey too. However, their journey is "laðsið" (Exodus, 1. 44a). The Egyptian armies are described as already located in Hell in a way that is resonant of the Beowulf poet's characterisation of Grendel as an inhabitant of Hell while he maintains a dwelling in the fens not far away from Hrothgar's Heorot. While it is not the place to argue whether or not the Old English Exodus was actually influenced by the motif of the Harrowing, it must be stated that the Egyptian exile-cities resemble Hell in two respects; namely, they are constrictive, and the life in them is represented as exile from a more prosperous state. ${ }^{20}$ Also, the affective poetics of the passage create a vivid contrast between the hateful inhabitations of Egyptian cities and Israel's longing for "leofes siðes" [beloved journey] (Exodus, 1. 53b). The constriction and confinement that characterises the stasis of the life in the cities of Egypt is contrasted with the movement in which the Israelites engage. The passage above punctuates the description of the Egyptians dying with three mentions of the Israelites leaving the confines of the city. Their movement also ties them to the destroyer of the Egyptians, the Passover angel, who "wide scrað" [flew far] (Exodus, 1. 39b) over the city.

19 The identification of the Egyptians with the devils is also telling: "heofon pider becom, druron deofolgyld" [heaven came down - the idols came] (Exodus, 11. 46-47). Irving in his edition claims "heofon" is God himself (Irving 1953: 69). Bammesberger supports the common practice of emending the word to "heofung", 'lamentation' (Bammesberger 2013: 276). He claims this translation explains "the Egyptians' dire situation" (Bammesberger 2013: 276).

20 James Earl claims that the imagery of binding present in these lines is influenced by the topos of the Harrowing of Hell. The Harrowing, as he claims, also influences lines 43-48: especially the verse "heofon pider becom" evokes the description of Christ's descent. The imagery of binding used in the fragment (the Egyptians have their hands locked) also parallels the idea that Christ binds Satan in hell (Earl 1970: 569). Earl compares these lines to two descriptions of the Harrowing in Old English poetry: Christ and Satan (1l. 441-444) and Christ II (11. 731-732) (Earl 1970: 569). 
The constricted and confined existence and demise of the Egyptians is informed by the poet's technique of contrast and inversion that he uses throughout the poem; the Egyptians' urban existence is depicted in terms of exile, which would seem to be more appropriate for the poem's description of Israel's exile. First, while God promises Moses and Israel land and victory, he deprives Egypt of the prosperity that in Old English poetry is traditionally associated with the life within the protection of a settlement. In the Old English poetic account of the exodus, the loss of treasure and hall-joys that the Egyptians face compounds the tenth plague inflicted on them by God

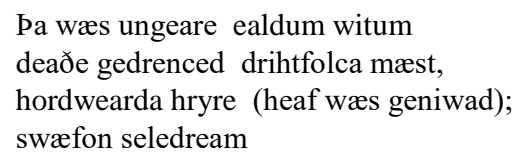

Then a vast number of people, of the treasure-watchers, was completely drowned in destruction and death by ancient punishments - the lament of renewed - hall joys slept, deprived of wealth.

(Exodus, 11. 33-36)

The Egyptians are described in terms of the deprivation of the prosperity that evokes an exile's fate; paradoxically, even as inhabitants of cities they suffer afflictions that are characteristic of an exilic existence. The state of deprivation of land and possessions characterises exiles as Stanley B. Greenfield observes in his study of the formulaic descriptions of exiles in Old English poetry. The poet's comment that the enemy of Israel was bereaved emphasises their loss. Greenfield also identifies a formulaic pattern expressed with an instrumental or genitive form of the thing removed from its owner collocated with the past participle of one of the verbs of deprivations, verbs that include bereafian (Greenfield 1989: 127). The emphasis laid on the perception of the Egyptians as city and hall-dwellers is undercut by the poet's ironic transference of a formulaic expression that commonly emphasises an exile's state of deprivation from the homeless Hebrews to Egyptians who are now inflicted with the loss of their dear ones: "feond [MS freond] wæs bereafod" (Exodus, 1. 45b). The killing of the first-born is described as an attack on their city, a siege, in which the defenders of the city are also destroyed. The kenning that describes the first-born, "sele-dreamas" [hall-joys] (Exodus, 1. 36b), suggests that their death causes the ultimate demise of prosperity within the penetrated walls of their cities.

The poem's imaginative blending of city-scape and journey across the desert and the sea generates a conceptual conflation and reversal of urban and exilic imagery. Paradoxically, it is the Israelites in the Old English Exodus who epitomise a spiritual ideal of city-dwelling despite their exilic status. As they walk across the desert, the Israelites are described as magburh, a compound invented 
by the Exodus poet that literary means 'family-city'. The Israelites travel "in a moegburh [family-enclosure], meaning that they remain in a type of a city after leaving behind the civilisation of the Egyptians" (Ferhatović 2019: 71). While Denis Ferhatović seems to suggest that the Israelites resemble a city, in essence they form an opposite of a conventional image of a community centred around a hall. In contrast to the inversion of the conventional idea of the hall as a symbol of order and continuity, Israel's maegburh is an inversion of the conventional image of a community insofar as it is displaced from a fixed geographical location that symbolises order and continuity. Its order and continuity, however, are long-lasting and generative of a new continuity, as the typological relationship between Israel's generations and future communities made by the poet implies.

In the poem, a reversal of symbols that derive from the traditional representations of halls and fortresses in Old English poetry as protective spaces and representations of prosperity serve to sustain the allegory dimension of the text. Such reversals of symbols that are related to city life and exile find a clear parallel and, conceivably, a source in Bede's commentaries. The image of the family-enclosure is influenced by the patristic idea of exile as a type of spiritual migration ruminated upon by Christian audiences. In the light of Bede's exegesis, the poem's original audiences may well have been prompted to understand the maegburh of the Isralites as a figure of the Church. As has been observed by a number of critics, the figurative signification of magburh as a type of Christian community is signalled by the poet's description of the protecting cloud pillar as a tent and sail. There has been a long-standing agreement that the sail and tentage imagery developed by the poet sustains an allegorical image of the Israelites as a figure of the Christian church. ${ }^{21}$ The pillar that covers and protects the Israelites from the blazing sun is simultaneously, and paradoxically, described as a sail and a sailyard on which the cloth of a tent is supported.

21 Peter J. Lucas claims that "the exodus is clearly equated with the journey of Christians (eðellease 534) through life" (Lucas 2020: 58). The ship of the Church may be identified at 80-84, "with its mast and sailyard which was the cross" (Lucas 2020: 58). Daniel Anlezark notes a relationship between Israel and Noah's ark as types of the Church in Exodus: "The commonplace of the Church as a ship, which lies behind the metaphor, is inseparable from the type of the ark" (Anlezark 2006: 201). Miranda Wilcox claims that "the Exodus poet's double conceit of ship and tent was likely inspired by the linking of Peter and Paul by Arator and Bede" (Wilcox 2011: 140). She claims that "Arator and Bede explore the metaphorical possibilities of tent-making in relation to Paul's role as an evangelist in Acts by equating tent-making with pastoral catechesis. Just as Paul constructs tents, his words construct the church whose structure shades the travelling inhabitants from inclement weather, the storms of temptation and heat of the secular society" (Wilcox 2011: 137). Since Wilcox claims that the Exodus poet was exposed to Arator's poem during his education (Wilcox 2011: 129), she argues for a later date of the poem's composition (Wilcox 2011: 130). 


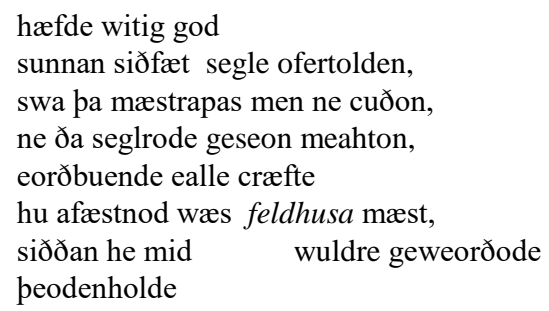

the wise God had veiled the sun's course with a sail, though in a way that people were unaware of mast-ropes, nor could the earth-dwellers, for all their skill, see how the sailyards, the mightiest tent, was tied, when he gloriously honoured the loyal nation.

(Exodus 11. 80b-87a)

In addition, the Israelites can see the sails towering high: "hu pær hlifedon halige seglas" [(the hall army saw) how the holy sails towered high] (Exodus, 1. 89). The image of the tent evokes the tabernacle in which God was worshipped by the Israelites during their journey across the desert. In Bede's biblical commentaries, the tabernacle is a typological image of the Christian community and the Church, an image that in turn evokes the idea of Christian life on Earth in terms of an exile and the displacement of humanity from the true homeland. The rhetorical trope of magburh used in Exodus supplements and supports the patristic conception of Civitas Dei peregrina. Its protective enclosures that separate the Israelites from natural and human evils are tents, which were understood also figurally as types of the Church. In the context of the sustained contrast between the Egyptian evil cities and Israel's exile, this rhetorical trope prompts an allegorical reading of the Israelites as the Church. The inversion of the imagery of the imagery and exile and urban life, arguably, serves to unveil the hidden significance. The extended and sustained contrast between the Israelites as seafarers and the Egyptians as city-dwellers thus serves to sustain a larger allegorical pattern in the poem in which the Egyptians represent a city of men and the Israelites an Old Testament prefiguration of the City of God.

\section{Biblical history and typology}

While the allegorical dimension of the text presents the travelling Israelites as the Church, the poem's polyvalency accommodates an addition typological link between the historical Israelites travelling to the land of Canaan and the Germanic ancestors of the early medieval English people who conceived of their historical journey from Germania to England in terms of a new exodus. The typological link is, arguably, sustained by the poet's introduction of Germanic kinship values that colour his presentation of the Israelites' moegburh. While biblical commentaries evade the questions of social class, Exodus is coloured by the 
secular and Germanic aristocratic considerations of rank and kinship. As the Israelites leave the shore, the poet describes three tribes that cross the Red Sea. The tribe of Judah comes first. The Old English rendering provides focus on their kinship, tribal identity and Moses's leadership and land-right:

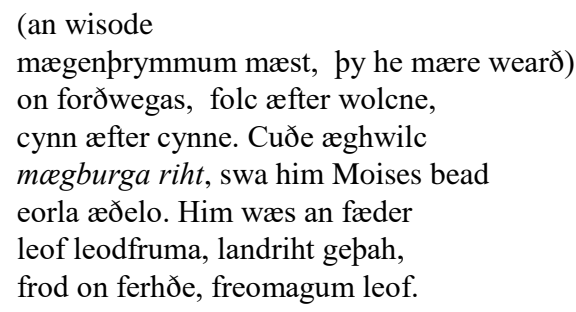

One man guided that greatest of glorious forces on the paths ahead, the nation under the clouds, tribe after tribe - for that he became famous. Each one knew his tribal right, as Moses had instructed them, the lineage of noblemen. For them there was one father, beloved origin of the people, he received the land-right, wise in spirit, dear to noble kinsmen.

\section{(Exodus, 11. 348b-355b, emphasis mine)}

In the biblical account of the exodus, the migration of the Israelites is temporary, as the tribes are promised land and land-rights on account of their covenant with the God of Abraham. ${ }^{22}$ Their origin and the memory of the covenant is remembered and transmitted by the elders who have the skill of tracing the ancestry of each tribe ("mæg-burge", Exodus, 1. 360a). All of the tribes that are crossing the sea have the right to claim the land on account of their genealogy; the meaning of "mæg-burge" in line 360a is 'ancestry, genealogy'. The second meaning of "mæg-burg", used earlier to describe Israel as a metaphorical city of exiles on the pilgrimage, is also evoked by the repetition. It is significant that the poet refers to "mægburga riht" in the plural.

Israel's progress across the sea-bed is narratively suspended by a digression that introduces into the poem two Old Testament stories, namely, the story of Noah and the flood and story of the covenant between God and Abraham. Noah and the ark are mentioned first.

22 According to two of the poem's recent editors, Irving and Lucas, "an fæder" must refer to Abraham, while "landriht" refers to the promise of Canaan. Irving claims that "it seems probable that the poet had in mind here the traditional etymological interpretation of the name Abraham (Irving 1953: 89). Peter J. Lucas claims that in the noun foeder in line 353 "the reference is to Abraham" (Lucas 2020: 122). More recently, Samantha Zacher has argued that the reference is not to Abraham, but to Jacob, as he is the father of the twelve tribes that are crossing the sea (Zacher 2013: 59). Whoever is the subject of the reference, the digression presents the voyage as a progress to the promised land. 


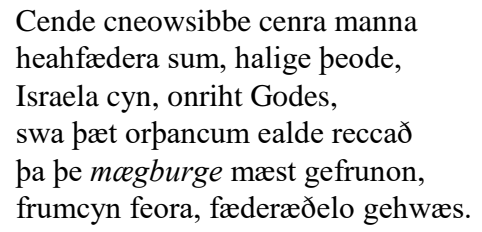

A certain one of the patriarchs begot a generation of brave men, a holy people, the nation of Israelites, the upright of God, just as the elders recount skilfully, those who have most studied the distant tribal origin, the noble pedigree, of each great house.

(Exodus, 11. 356a-361, emphasis mine)

Since the ark is typologically the Church, the verse "cneowsibbe cenra manna" [a generation of brave men] refers to Noah and his family, the Israelites crossing the sea and the Church including early medieval English people. The typological link between Noah, the Israelites and the English established in the digression suggests that persons and peoples from the Old Testament narrative prefigure the Church in which the English represent the fulfilment of the Old Testament type. This typological link between Israel and the English is strengthened by another familiar heroic trope, namely, the value placed on kinship ties and tribal origin. The magburh in the digression is a historically inclusive sign that encouraged the early medieval English audience to include their own ancestors and themselves in the concept of the metaphorical city that is not geographically anchored and in the process of the travellers constant travel to their promised destination.

\section{The anagogical level of the city imagery}

Another metaphorical city in Exodus is described in the passage that relates the crossing of the Israelites and the destruction of Pharaoh's army. As they part, the waters of the Red Sea form "weall-fæsten" [ramparts] (Exodus, 1. 484a), "wægas" [walls] (Exodus, 1. 484b), and "meretorras" [sea-towers] (Exodus, 1. 485a). They are also called "beorhhliðu" [ramparts] (Exodus, 1. 449a), like the ones inhabited by the Ethiopians in line 70a ${ }^{23}$ While many readers of the poem have attended to the fragment's urban imagery, they have discussed it as an act of creation and omitted the possible typology of the Judgement Day. Lori Ann Garner, for example, observes that the Exodus poet changes the simile of walls of water in the biblical source into an architectural metaphor to represent a structure formed of the ancient foundations at the bottom of the sea, the walls of waters and the roof of heaven (Garner 2011: 126-127). Denis Ferhatović explores the partition of the sea 
as an act of urban construction, "a Red-Sea city" (Ferhatović 2019: 74-75). ${ }^{24}$ What escapes their critical attention is, however, the fact that the architectural metaphor is mostly developed not in the description of the Israelites' crossing but in the account of Pharaoh and his army's death. The city imagery thus serves to dramatize their destruction rather than Israel's crossing of the Red Sea.

The Red Sea is a fortification in which the Egyptians are destroyed by the God of the Israelites.

\author{
Folc wæs afæred; flodegsa becwom \\ gastas geomre, geofon deaðe hweop. \\ Wæron beorhhliðu blode bestemed, \\ holm heolfre spaw, hream wæs on yðum, \\ wæter wæpna ful, wælmist astah. \\ Wæron Egypte eft oncyrde, \\ flugon forhtigende, fær ongeton, \\ woldon herebleaðe hamas findan - \\ gylp wearð gnornra. Him ongen genap \\ atol yða gewealc, ne ðær ænig becwom \\ herges to hame, ac behindan beleac \\ wyrd mid wæge
}

\begin{abstract}
The nation was afraid, the flood-terror overcame their gloomy spirits, the ocean threatened with death. The steep cliffs were wet with blood, the sea spewed gore, a roar was in the waves, the water full of weapons, the slaughter-mist climbed up. The Egyptians were then routed, they fled terrified, realised the disaster, the battleshy wanted to find their homes, their boasting became more lamentable. The terrible rolling of the waves darkened over them, none of that army came home, but fate enclosed them from behind with the wave.
\end{abstract}

(Exodus, 11. 447a-458a)

The walls of water are imagined as a hall or fortress whose walls are stained with blood: "blode gestemed" [wet with blood] (449b). The sea is full of weapons: "wæpna ful" [full of weapons] (Exodus, 1. 451a). As the sea-hall is a place of destruction, the Egyptians, ridiculed by the poet as battle-shy, seek refuge in their homes, which indicates cowardice and condemns the Egyptians in the eyes of the audience, familiar with heroic conventions.

The Old English account of the death of the Egyptians in the Red Sea depicts the urbanised space of the sea-hall as giving way to the essential wildness of the elements that constitute it. The walls of waters, earlier described as a fortress, melt and collapse:

24 He claims that "Moses tames the hostile landscape with God's help, even incites it to turn into a more human habitation" (Ferhatović 2019: 74). He claims, "with the Red Sea City so far we have the elusive burh with its foundations, ramparts, and passageways functioning as valuable artefacts at the intersection of the elements (the sea, the Earth, and the air)" (Ferhatović 2019: 75). 


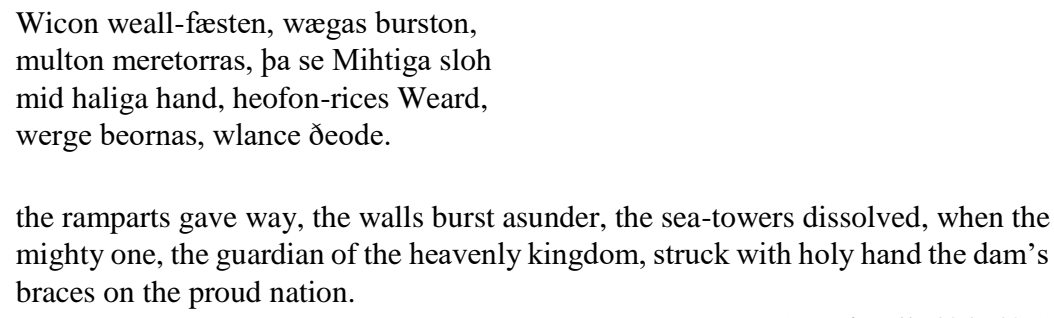

(Exodus, 11. 484-487)

As Daniel Anlezark remarks, "the sea is simultaneously collapsing towers (485a), a proud warrior $(459,474)$ and God's weapon $(485 \mathrm{~b}, 495)$. The 'terrible rolling of the waves' (456a) and fate's blocking of their retreat with the wave (457b458a) lead into the image of the walls of water as an army waiting to rush into battle" (Anlezark 2006: 204). The walls of water that protected the Israelites from the destructive natural elements as well as from their human enemies trap the Egyptians. The sea is the conduit of God's destruction; God's punishing rod and sword descend and shatter the hall in which Israel's enemies remain trapped:

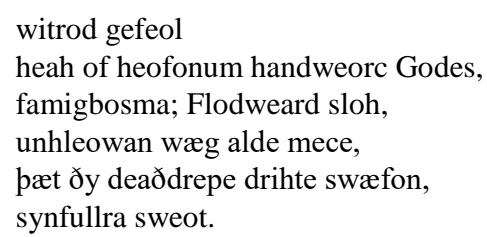

The rod of punishment fell high from the heavens, the handiwork of God - the foamy-bosomed one, the guardian of the flood, struck the unsheltering wall with the ancient sword, so that the troops, the sinful band, perished by the death-blow.

$$
\text { (Exodus, 11. 492b-497a })^{25}
$$

The army is ultimately destroyed, swept away from the bottom of the sea by the violent rush of waters. The poet uses irony to represent the death of the Egyptian army as a deep reward, deop lean, as, drowned in the sea, none of them survive to return home and relate the outcome of the battle with God in the protective confines of their boroughs:

Egyptum wearð

pæs dægweorces deop lean gesceod,

forðam pæs heriges ham eft ne com

ealles ungrundes ænig to lafe,

pætte sið heora secgan moste, 25 It is notable that while in Beowulf the negative halls remain intact while human settlements
suffer destruction, in Exodus, the Egyptian city is destroyed. 
bodigean æfter burgum bealospella mæst, hordwearda hryre, hæleða cwenum, ac pa mægenpreatas meredeað geswealh, spelbodan eac.

The deep reward for the day's work became a punishment for the Egyptians, because none of all that capsized army came home afterward as a survivor, so that the messengers must say of their journey, announce across the cities, the greatest death notice, to the men's wives, the fall of the treasure-guardians, because the seadeath had swallowed the force of the attackers.

(Exodus, 11. 506b-514a)

The Egyptians are characterised by an inordinate longing for their homeland, a longing that ties them to the world and sets them apart from the peregrinating and homeless Israelites. Also, the ironic remark of the reward of death that the Egyptians receive in the depths of the Red Sea recalls the deep journey of Noah from the digression, where Noah and his three sons are described as travelling across "pone deopestan drencefloda" [the deepest drowning floods] (Exodus, 1. 364).

The destruction of Pharaoh's army in the Red Sea has been interpreted as a prefiguration of the eschaton, a vision of the Day of Judgement. ${ }^{26}$ I would like to argue that the urban imagery in the fragment serves to reinforce the anagogical treatment that this portion of the narrative receives in the hands of the Old English poet. The poet's emphasis on destruction, rather than on a formation or construction of the nautical city-scape provides an eschatological perspective on the death of Pharaoh and his army. In fact, it is the association of hall imagery with Hell, also used earlier in the poem in the description of the Egyptian cities, that colours the doomsday imagery applied to the portrayal of death and destruction at this most climactic episode in the poem. In the light of the poem's ethical distinction between the pilgrimage away from the world and its possessions and Egypt's commitment to worldly material values, the desire of the Egyptians to return to the protective confines of their homes, and cities, condemns them. Throughout the description of their destruction, the Egyptians represent cives terreni; their destruction reflects the eschatology of earthly political structures. Again, space is constrictive to the Egyptians. The drowning of the Egyptian army in Exodus might thus be understood as a foreshadowing of the destruction of the earthly city that is to happen at the end of times.

\section{The tropological level of the hall imagery in Exodus}

Once the Egyptian army is destroyed in the sea, Moses delivers a speech to the Israelites prefaced by the poet's introduction. The introduction to Moses's speech

\footnotetext{
26 In his edition of the poem, Peter J. Lucas posits that the description of Pharaoh's demise has strong overtones of Judgement Day descriptions (Lucas 2020: 46).
} 
offers an interpretative key to the meanings veiled under the letter of the Old Testament story of exodus. ${ }^{27}$ The message requires spiritual interpretation on the part of life's interpreter, the life-guardian, who must unlock its contents with the keys of the spirit.

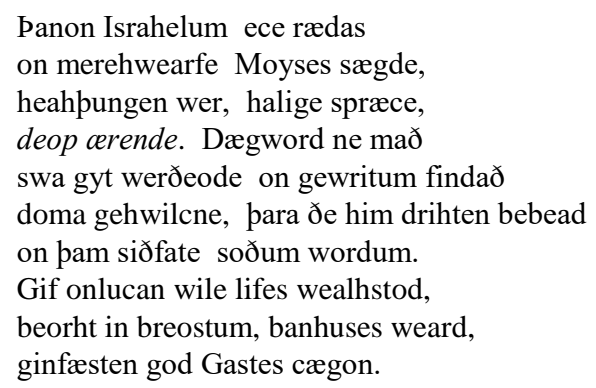

after that Moses, man of great virtue, announced eternal counsels to the Israelites on the sea-shore, a holy speech, a deep message. So the nations still relate that day's work, in writings they find each one of those decrees, which the Lord commended to them in true words during that journey, if life's interpreter, the body's guardian, wishes to unlock the abundant good, bright in the breast, with the keys of the spirit.

(Exodus, 11. 516a-525b)

The poet's idea of unlocking "deop ærende" [a deep message] (Exodus, 1. 519a), as a rhetorical remark pointing to multiple dimensions of the historical narrative, is deeply ironic in terms of the events in the narrative of Exodus that it evokes. First, it grimly refers to the deep reward of death that the Egyptians were given in the sea. The statement that the message is profound, "deop", evokes the depths of the sea, whose uncovered bottom figures as an unveiled mystic signification of the scriptural narrative. Second, the action of revealing the hidden meaning of the narrative, conceived of as unlocking, reminds of a statement that the poet makes earlier in the poem referring to the Egyptian poets having their hands locked, or unable to sing of the sorrow afflicted on their nation. ${ }^{28}$ Thirdly, the adjective evokes the poet's description of Noah travelling across "pone deopestan drencefloda" [the deepest drowning floods] (Exodus, 1. 364). The poet's wordplay on the adjective "deep" brings attention to the spiritual stasis of the Egyptians at the time of their violent death. Juxtaposing their stasis with descriptions of travel, the wordplay also suggests that an inability to ponder one's

27 It has often been suggested that the entire Pentateuch, rather than the Book of Exodus, is indicated in the fragment.

28 Another important image of constriction is thus articulated in the depiction of the poets having their hands paralyzed, "wæron hleahtorsmiðum handa belocene" [the hands of the mockers were paralyzed] (Exodus, 1. 43). "Hleahtorsmiðum" (translated as 'mockers' by Daniel Anlezark) is likely to indicate poets who "should be silent, unable to use their hands gomenwudu gretan 'to play the harp"” (Lucas 2020: 80). 
life as spiritual exile "locks" and fixes persons and leod in a similar spiritual stasis. The hermeneutic act on the part of the reader is thus not only juxtaposed to the stasis of the life in the city but also imagined as a liberating action, like the Israelites' journey away from the Egyptian cities.

The metaphorical movement forward of the mystery that emanates from the counsel imitates the Israelites journey from Egypt. The poet states that once the mystery of the letter is unveiled, its wisdom rushes forward: "run bið gerecenod, ræd forð gæð” [The mystery is explained, counsel flows forth] (1. 526). The poet's use of a verbal phrase that resembles the earlier descriptions of exile and travel in the poem suggests that the poem's narrative of the departure of the Israelites from Egypt and their migration figures the process of the unveiling of the message of the story.

This wisdom, as transmitted in the poem, reflects on the relationship between peregrini and the land that they receive for temporary use, a gift that is to be taken away at the end of times.

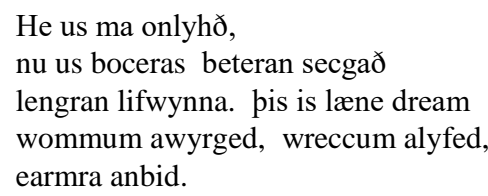

he enlightens us more - now scholars explain to us better concerning longer-lasting joys in heaven. This is a transitory happiness, cursed with sorrows, granted to exiles, a tarrying for wretched ones.

(Exodus, 11. 530b-534a)

The idea that material values are loene "loaned", "on loan", is commonplace in Old English poetry. The adjective accretes all the religious connotations of transience, to which all things material are subject, as well as God's grace in the dispensation of wealth for temporary use. Intratextually, the adjectives allude to the Egyptians' loaned lives, "lænes lifes" (Exodus, 1. 268a) that they have lost in the sea. Like the time on Earth given to the Egyptians in lease, the Israelites also hold material benefits that will eventually be taken away.

The poet's teaching is, significantly, stated in terms of contrast and reversal that confuse and conflate the symbolisms of city life and exile. With land and material possessions dispensed on temporary loan, life on Earth is conceived as a sorrow-afflicted exile, a transitory joy, full of sorrow. The present life is imagined as a sojourn in a guest-hall, in which the reader is supposed to consider Hell, an everlasting dwelling place: 


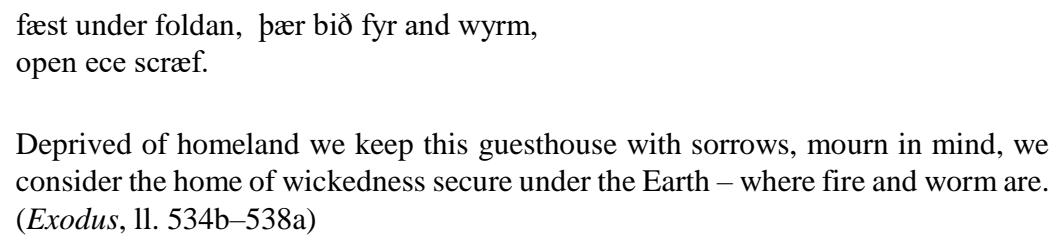

The guest-hall in which the elect sojourn for their duration of the pilgrimage is given to them for temporal use only. The devils share dominion with old age and death. ${ }^{29}$ People must be mindful of Hell and make only provisional use of their earthly possessions so that they keep reorienting their exile to their proper destination. The fragment inculcates the proper attitude to land and material values. The enjoyment of land is temporary. The idea of the world as a guest-hall corresponds to the Augustinian perception that Christians as exiles are not entitled to the full possession of the Earth. In the homiletic digression, the heroic hall is also a fixed location, contrasted with the migratory existence.

The sustained imagery of contrast and reversal, which characterises the earlier parts of the poem, is, however, suspended as Moses commences his speech to the survivors. In his retelling of the promise made by God of Canaan, Moses represents Canaan as a fortress or a hall, not unlike the cities of Egypt. His description is influenced by Germanic secular values that underlie the typical and formulaic description of hall life in such poems as Beowulf. Israel is given people, a borough, and rings. At times, the poet describes the treasure sharing among the sea-remnant, the treasure including shields and clothing as well as the fine cloth and gold that belonged to Joseph. The theme of the covenant itself, which not only originates in the biblical source but also in exegetical works on the exodus, is couched in terms that evoke the heroic military narratives of Beowulf or the Battle of Maldon. If respected by Israel, the covenant will result in bringing future victories to Israel as well as the promise of the land between the two seas; it is God rather than Israel that is attributed agency in the process of the conquest of land: "ge feonda gehwone forð ofergangað, gesittað sigerice be sæm tweonum, beorselas beorna" [you will overcome each enemy, occupy a victorious realm between the two seas, the beer-halls of men] (Exodus, 11. 562a-564a). The reversal of the symbol that ends the poem also presents a hall as an image of divine reward; as the Israelites will overcome all enemies, they will establish the beer-halls of men in the new land between the two seas.

The shift from the allegorical to secular perspective, or the religious reversal of symbols to the secular association of a life in the hall, with life, prosperity and

29 Manish Sharma claims that the Egyptians in the Old English Exodus "practice a false economy whereby they seek to repay (gyldan, 1. 150) the Israelites for the services rendered on their behalf by Joseph" (Sharma 2011: 179). 
goodness, may be determined by a typological interpretation of the exodus that informs the poet's retelling of the biblical source. If the arrival of the Israelites at the shore prefigures Christian redemption, and the destruction of the Israelites prefigures the Judgement, the hall that dominates in Moses's description of Canaan stands for heaven. The narrative proximity of the destruction of the Egyptians in the Red Sea depicted as a destruction of a hall forms an exegetically appropriate contrast for the establishment of Canaan as a prefiguration of salvation.

Another explanation for this shift can also be offered. Knowledge of the secular trope of the hall is required for the audience since the traditional poetic idea of the hall is a hermeneutic key to unlocking the letter of the narrative and unveiling its allegorical meaning. It is therefore appropriate that the concept of the hall is evoked by the poet in a form that is directly extrapolated from the heroic secular tradition. It is the strangeness of the inversion of the tropes that calls for an exegetical explication; the conventional secular imagery has been inverted in the poem during a process of facilitating the reader's reception of manifold allegory. The poem's secret meaning can only be reached by the reader who is able to transcend the symbolism he or she falls back upon in the reception of secular texts. The order of presenting the inverted imagery as first and its conventional form as second is also appropriate. The temporary life and its political and ideological dimension is provided a sub specie eternitatis perspective. The order of presentation guides the reader's movement from the allegorical perspective sustained in the bulk of the poem to his or her life experience in which the hall functions as a symbol of social order, rank and class. The early medieval reader thus contemplates the social order in terms of the covenant that is the subject of the poem; the beer-halls which the moegburh of Israel establishes establish on the strength of the covenant between them and God of Abraham in the poem serve as types of the early medieval English political order that is depicted by means of an architectural metaphor in descriptions of the hall in Old English heroic poems.

\section{Conclusion}

Exodus presented Old English audiences with two distinct typologies, one religious and biblical, the other secular and based in the poetics of heroic verse. The poem demonstrates a flexibility in evoking an image of the life in the hall in bono and in malo, a flexibility that characterises Bede's biblical commentaries. As the same image may function in the poem on two levels, the cities in the Old English Exodus may exist on many planes. While the commitment to their cities that the Egyptians exhibit is the symptom of their evil, the cities that the Israelites are promised to establish between the two seas are symbols of their covenant. 
The homiletic digression that prefaces Moses's speech, in which he articulates the terms of the promise, provides a Christian perspective on the Old Testament story from which political dominion over land must not be practised as an end in itself; rather, land is a provisional and temporal means for a chosen nation to flourish in the world that is transient.

While earlier criticism elucidated the possible influence of biblical exegesis on the poem, providing readings of verses that were supposedly inspired by particular commentaries, it is concluded here that the kind of poetic exegesis practiced by Old English poets requires a method that acknowledges the difference between the exegetical and scholarly approach of such biblical commentators as Augustine and Bede and the typological approach that characterises poetry addressed to both religious and secular audiences.

\section{REFERENCES}

\section{PRIMARY SOURCES}

Anlezark, Daniel (ed.). 2011. Old Testament narratives. Harvard University Press.

Augustine. 1997. On Christian teaching (translated by R. P. H. Green). Oxford University Press. Augustine. 2003. City of God (translated by Henry Bettenson). Penguin Books.

Bede. 2006. On Ezra and Nehemiah. Liverpool University Press.

Bede. 2008. On Genesis (translated by Calvin B. Kendall.). Liverpool University Press

Bjork, Robert R. (ed.). 2014. Old English shorter poems. Vol. II: Wisdom and lyric. Harvard University Press.

Irving, Edward B, (ed.). 1953. The Old English Exodus. Yale University Press.

Lucas, Peter J. (ed.). 2020. Exodus (3rd edn). Liverpool University Press.

North, Richard \& Michael D. J. Bintley (eds.). 2016. Andreas: An edition. Liverpool University Press.

\section{SECONDARY SOURCES}

Anlezark, Daniel. 2006. Water and fire: The myth of the flood in Anglo-Saxon England. Manchester University Press. DOI: 10.7765/9781526129659

Baker, John \& Stuart Brooks. 2013. Beyond the burghal hidage: Anglo-Saxon civil defence in the Viking Age. Brill.

Bammesberger, Alfred. 2013. Old English hēofon pider becōm (Exodus, 46B). Neuphilologische Mitteilungen 114(3). 275-278.

Claussen, Martin A. 1991. 'Peregrinatio' and 'peregrini' in Augustine's 'City of God'. Traditio 46. 33-75. DOI: $10.1017 / \mathrm{S} 0362152900004190$

Discenza, Nicole Guenther. 2017. Inhabited spaces: Anglo-Saxon construction of space. Toronto University Press. 
Draper, Simon. 2008. The significance of Old English burh in Anglo-Saxon England. Anglo-Saxon Studies in Archaeology and History 15. 240-253. DOI: 10.2307/j.ctvh1dw9r.8

Earl, James W. 1970. Christian tradition in the OE 'Exodus'. Neuphilologische Mitteilungen 71(4). 541-570.

Ferhatović, Denis. 2019. Borrowed objects and the art of poetry: Spolia in Old English verse. Manchester University Press. DOI: 10.7765/9781526131669

Garner, Lori Ann. 2011. Structuring spaces: Oral poetics and architecture in early medieval England. Notre Dame University Press.

Greenfield, Stanley B. 1989: Hero and exile: The art of Old English poetry. The Hambledon Press.

Hopkins, Stephen C. E. 2018. Snared by the beasts of battle: Fear as hermeneutic guide in the Old English Exodus. Philological Quarterly 97(1). 1-25.

Howe, Nicholas. 1989. Migration and mythmaking in Anglo-Saxon England. Yale University Press.

Howe, Nicholas. 2008. Writing the map of Anglo-Saxon England: Essays in cultural geography. Yale University Press.

Hume, Kathryn. 1974. The concept of the hall in Old English poetry. Anglo-Saxon England 3. 63-74. DOI: 10.1017/S0263675100000582

Lapidge, Michael. 2006. The Anglo-Saxon library. Oxford University Press. DOI: 10.1093/acprof:oso/9780199239696.001.0001

Luria, Maxwell. 1981. The Old English Exodus as a Christian poem: Notes towards a reading. Neophilologus 65(4). 600-606.

Michelet, Fabienne L. 2011. Lost at sea: Nautical travels in the Old English Exodus, the Old English Andreas, and the accounts of the adventus Saxonum. In Sebastian I. Sobecki (ed.), The sea and Englishness in the Middle Ages: Maritime narratives, identity and culture, D. S. Brewer. 59-80.

Parsons, David N. \& Tania Styles. 2000. The vocabulary of English place-names: Brace-Caster. Nottingham: Centre for English Names Studies.

Sharma, Manish. 2011. The economy of the word in the Old English Exodus. In Michael Fox \& Manish Sharma (eds.), Old English literature and the Old Testament, University of Toronto Press. 172-194. DOI: 10.3138/9781442664296-007

Vickrey, John F. 1972. 'Exodus' and the battle in the sea. Traditio 28. 119-140.

Walton, Audrey. 2013. "Gehyre se ðe wille": The Old English Exodus and the reader as exegete. English Studies 94(1). 1-10. DOI: 10.1080/0013838X.2012.739811

Wilcox, Miranda. 2011. Creating the cloud-tent-ship conceit in Exodus. Anglo-Saxon England 40. 103-150. DOI: $10.1017 /$ S026367511100007X

Zacher, Samantha. 2013. Rewriting the Old Testament in Anglo-Saxon verse: Becoming the chosen people. Bloomsbury. 